\title{
Maintenance of diversity altered by a shift in dominant species: implications for species coexistence
}

\author{
Jennifer A. Dijkstra ${ }^{1,2, *}$, Larry G. Harris ${ }^{1}$ \\ Department of Biological Sciences, University of New Hampshire, Spaulding Hall, 46 College Road, Durham, \\ New Hampshire 03824, USA \\ ${ }^{*}$ Present address: 342 Laudholm Farm Road, Wells, Maine, USA
}

\begin{abstract}
Diversity can be maintained by the biological characteristics of species within communities, particularly dominant species. Invasions often result in shifts of dominant species. Despite the number of studies on invasion ecology, few have determined their long-term effect on diversity. In the present study, we coupled short- and long-term studies to examine the relationship between invasive species (colonial ascidians or sea squirts) and diversity and to discuss their implications for species coexistence. Diversity patterns between 2 panel studies (1979 to 1982; 2003 to 2006), one conducted before the establishment of invasive colonial ascidians, revealed an increase in species diversity. Short-term recruitment studies designed to elucidate mechanisms behind the patterns observed in our long-term studies suggest contrasting methods of maintaining diversity. Between 1979 and 1982, Mytilus edulis was a consistent spatial occupant whose hard shell provided secondary space for colonization by other species. In contrast, the 2003 to 2006 community was dominated by the seasonally abundant invasive colonial ascidians Botrylloides violaceus and to a lesser extent Didemnum vexillum, which do not provide secondary substrate. These species either senesce after reproduction or undergo seasonal regression and free space for colonization by other species. These studies suggest that the coexistence of species has shifted from a community in which diversity was maintained by secondary substrates to a community in which diversity is maintained by primary substrates. Additionally, they suggest that the community is undersaturated and could support more species, particularly those that seasonally utilize a limited resource (free space).
\end{abstract}

KEY WORDS: Species coexistence - Invasive species · Diversity - Species richness · Recruitment · Ascidians $\cdot$ Bivalves $\cdot$ Mytilus edulis $\cdot$ Botrylloides violaceus $\cdot$ Didemnum vexillum

Resale or republication not permitted without written consent of the publisher

\section{INTRODUCTION}

In recent years, considerable effort has been directed towards studying invasive species and their ecological impacts on communities and ecosystems. Introduced species have been found to substantially alter species composition and ecological interactions within the invaded community. For example, observations of subtidal communities in Long Island Sound, USA, have shown a substantial displacement of native species by invasive ascidians (Osman \& Whitlatch 1995a). Similar shifts have been found in the Gulf of Maine over a 25 yr period. Harris \& Tyrrell (2001) witnessed a change in the development of rocky subtidal communities, from a community that was historically comprised of kelp beds to a community dominated by invasive species, including a green alga (Codium fragile ssp. fragile), a bryozoan (Membranipora membranacea), and colonial ascidians (Diplosoma listerianum and Botrylloides violaceus). Recent studies in invasion biology have focused on identifying ecological components that render communities vulnerable to invasion (Levine \& D'Antonio 1999, Lonsdale 1999, Stachowicz et al. 1999, 2002a, Lundholm \& Larson 2004), examining characteristics that make species successful invaders (Levine 2000, Stachowicz \& Byrnes 2006), and understanding the interactive effects of invasions on communities and ecosystems (e.g. Stachowicz \& Tilman 
2005, Sala \& Knowlton 2006, Stachowicz et al. 2007). Despite this continuing research, the mechanisms underlying the impacts of invasions on biological diversity and species coexistence are still not well understood (Stachowicz et al. 2007).

The maintenance of species diversity is commonly thought of as coexistence of species that use similar resources (Simberloff \& Dayan 1991, Chesson 2000). As an example, assemblages of sessile invertebrates of fouling and cryptic communities feed on suspended material in the water column and require space for attachment. Diversity in highly competitive ecosystems can often be increased by the life-history characteristics or elimination of marine organisms (Dayton 1971, Sutherland \& Karlson 1977, Connell 1978, Sousa 1984). Many marine species are seasonally dominant or have finite life-cycles that allow other species to become established in communities during their absences (Yund et al. 1997, Stachowicz \& Byrnes 2006, Dijkstra et al. 2007a). During periods when competitively dominant species are absent, more resources (e.g. primary space) are available to other species (e.g. Sebens 1982). An alternative mechanism for increasing diversity in marine benthic communities is by providing a 3-dimensional surface that offers substrate for settlement of species (e.g. Jackson 1977, Osman \& Whitlatch 1995b, Barnes 2001, Reiss et al. 2003). However, not all established adults increase diversity; in fact, some may reduce diversity by preventing other organisms from settling on their surfaces (Buss 1979, Bryan et al. 2003, Joullie et al. 2003). Thus, displacement of one dominant species by another species can affect diversity and the mechanism(s) of its maintenance, depending on their use versus the creation of available space.

The purpose of the present study was to examine the influence of invasive ascidians on the mechanisms that maintain diversity and their implications for species coexistence in a marine epifaunal community in the southwestern Gulf of Maine, New Hampshire, USA. We compared 2 long-term studies conducted at the same location - the first conducted before the ascidians arrived and the second conducted post-invasion. Shortterm recruitment experiments were then designed to examine the influence of the dominant organisms in each community (pre-invasion and post-invasion) on species diversity. Results of these short-term experiments were compared with our long-term studies. Our pre-invasion dataset is an essential and unique component of our study, as most studies are only able to evaluate the impact of exotics after they have become established. Coupling short-term studies with pre- and post-invasion long-term datasets is critical to understand the mechanisms that underlay the relationship between invasions and community structure.

\section{MATERIALS AND METHODS}

Long-term experiments. Long-term comparisons of species diversity were quantified using 2 panel studies, conducted beneath a cement pier in Newcastle, New Hampshire, USA, at the University of New Hampshire's Coastal Marine Laboratory. The first study was initiated in 1979 with the goal of comparing succession between horizontal and vertical substrates (Harris \& Irons 1982). Here, 8 horizontal and 8 vertical, predatorinaccessible $0.1 \mathrm{~m}^{2}$ Plexiglas panels were deployed in July $1979 \sim 5 \mathrm{~m}$ below mean low water under the pier at the Coast Guard Station, Newcastle. This pier extends $\sim 0.5 \mathrm{~km}$ into the channel of Portsmouth Harbor. The benthic substrate at this site was composed of fine sand/mud mixed with boulders. From 1979 to 1982, the fouling community on the pier was dominated by sponges, mussels, anemones, and large barnacles (Harris \& Irons 1982). Soft corals, ascidians, bryozoans, and hydroids were less common and were interspersed throughout this assemblage. Panel arrays were suspended away from pilings to minimize predator access, though fish were not excluded. Any crabs or sea stars that were observed on the arrays were removed during monthly monitoring and photography. Identification and enumeration of individuals were conducted using the original photographic slides.

The second panel study was initiated in 2003 with the intention of determining any shifts in species composition and diversity and of assessing whether the maintenance of diversity had changed since the 1979 to 1982 study. The 2003 to 2006 study replicated the experimental design of the first study exactly, and panels were photographed monthly. Since the completion of the 1979 to 1982 study, 6 new species have become established in Portsmouth Harbor. These include the encrusting bryozoan Membranipora membranacea, the solitary ascidians Ascidiella aspersa and Styela clava, and the colonial ascidians Didemnum vexillum, Botrylloides violaceus, and Diplosoma listerianum. By 2004, all 3 colonial ascidians and $M$. membranacea occupied panels at our study site in Newcastle and were also found within the fouling communities occupying the beams supporting the pier. The 2 solitary ascidians had not yet been observed at this site, but do occur within the Portsmouth Harbor Region.

Slides and photographs of horizontal panels (facing the substrate only; $\mathrm{n}=8$ ) and vertical panels (1 side only; $\mathrm{n}=8$ ) taken approximately monthly from 1979 to 1982 and 2003 to 2006 ( 1200 images) were digitized and downloaded into Adobe Photoshop 7.0. A few months from the 1979 to 1982 dataset are missing. Therefore, we excluded similar months from the 2003 to 2006 dataset for statistical analysis. For instance, if November 1980 were missing, then the equivalent 
month (November 2004) of the 2003 to 2006 dataset would be excluded from the analysis. Data presented here are from July (1979 and 2003, respectively) to April (1982 and 2006, respectively). All individuals were counted and identified to species. The only exceptions to this occurred due to the difficulties of enumerating stolonating organisms and in differentiating epibionts from their basal individuals. Thus, abundances of hydroids were analyzed as percent cover, and Molgula sp./Obelia sp. were recorded as a species complex because Obelia sp. was a common secondary space occupant of the solitary tunicate Molgula sp. In addition to counting individuals, we recorded percent cover of the dominant structural members of each community (1979 to 1982, Mytilus edulis; 2003 to 2006, Botrylloides violaceus). Average monthly abundance data of individuals from horizontal and vertical panels were pooled for statistical analysis and ordination plots. Abundances from vertical and horizontal panels were pooled, as we wanted to compare total differences in community structure and composition. These data were used for statistical analysis and non-metric multidimensional scaling plot (nMDS) ordination. Comparison of community structure and composition between horizontal and vertical panels in 1979 to 1982 and 2003 to 2006 will be discussed elsewhere. A Kruskal-Wallis test on combined average monthly abundances of vertical and horizontal panels was used to detect differences in abundance (number of individuals; exception was hydroids) within a species between the 2 communities (1979 to 1982 and 2003 to 2006). A 1-way ANOVA was used to determine differences in average number of species and abundances of individuals found on panels per month. To determine whether the changes in species richness and abundance between the 1979 to 1982 and 2003 to 2006 communities were the result of the inclusion of the invasive species themselves (rather than their effects on the community), we performed calculations with and without invasive species.

To examine divergence in faunal composition between the 2 studies, a Bray-Curtis similarity matrix was constructed using abundances that were square-root transformed (Clarke \& Warwick 2001). A nMDS plot and a 1-way analysis of similarities (ANOSIM) were calculated to examine differences in faunal composition between the 2 studies. The nMDS is a method that preserves species-specific formation and is sensitive in detecting changes in assemblage patterns (Clarke \& Ainsworth 1993). ANOSIM is a non-parametric permutation test that applies the same (rank) similarity matrix used for nMDS ordination (after Clarke \&Warwick 2001).

Discriminator species were calculated between 1979 to 1982 and 2003 to 2006 using the SIMPER statistic (SIMilarities PERcentages). A discriminator species has a relatively high and even distribution in most areas of one assemblage, but is rare or absent in areas of another assemblage. Discriminator species were calculated by first computing the average dissimilarity in species composition between 1979 to 1982 and 2003 to 2006 (Clarke \& Ainsworth 1993). The overall average dissimilarity was then broken down into separate contributions from each species and the consistency (i.e. monthly) with which each species contributed to the overall dissimilarity. Thus, a good discriminator species not only contributes importantly to the overall dissimilarity, but does so consistently (Clarke \& Warwick 2001). Community analyses and graphs were generated using Primer 6.0 (Primer-E).

Short-term experiments. To determine the mechanisms driving diversity patterns in communities dominated by bivalves (1979 to 1982) and colonial ascidians (2003 to 2006), we conducted an experiment using 4 types of structural treatments: 2 types of biogenic structure (bivalves and colonial ascidians) and 2 controls (glue and no glue) and 3 sites. A total of 36, Plexiglas panels of $100 \mathrm{~cm}^{2}(\mathrm{n}=3$ for each treatment per site and $n=3$ for each control per site) were deployed in July and August 2004 and July 2005.

Trials were carried out using 2 treatments with $50 \%$ cover of either bivalves (Mytilus edulis and Anomia simplex) or colonial ascidians (Botrylloides violaceus, Didemnum vexillum, and Botryllus schlosseri) and 2 controls (panels with glue and no glue). Each trial was performed at a separate site and was done to test the repeatability of the experiment. Species were collected from floating docks and glued to panels with Superhold Plastic Surgery glue. For glue controls, $50 \%$ of the surface was randomly covered in glue. Panels were suspended from floating docks and hung horizontally, $\sim 0.5 \mathrm{~m}$ below the surface with experimental surfaces facing downward. Panels were left in the field for $2 \mathrm{wk}$, at which time they were collected and brought to the laboratory for analysis.

All individuals that settled upon adult individuals and free space on the panels were counted and identified to species (Pollock 1998, Bullard \& Whitlatch 2004). A randomized complete-block 1-way ANOVA, with treatment levels as the independent factor, site as the block term, and recruitment (species and individuals) as the dependent variable, was used to test for differences in community structure on secondary space (bivalves and colonial ascidians) and primary space (free space on panels with adult individuals) (Table 1). Tukey-Kramer analysis set to 0.05 significance level was used to detect differences in settlement of species and individuals across structural treatment levels. All statistical analyses were generated using JMP software $^{\circledR}$ (JMP 7, SAS Institute). To reduce heteroscedasticity, recruitment data were square-root transformed before analysis (Zar 1999). 


\section{RESULTS}

\section{Comparison between 1979 to 1982 (pre-invasion) and 2003 to 2006 (post-invasion) studies}

Three invasive species not present in the 1979 to 1982 community became key members of the 2003 to 2006 community (Table 2). They include the colonial ascidians Botrylloides violaceus and Didemnum vexillum and the encrusting bryozoan Membranipora membranacea. $M$. membranacea is a pioneer species and exhibited its greatest abundance during the first 3 mo of community development (July to September; J. A. Dijkstra unpubl. data).

Differences in abundances of taxa were determined between 1979 to 1982 and 2003 to 2006 (Table 2). While differences in abundances of certain taxa were found between 1979 to 1982 and 2003 to 2006, we did not observe taxonomic losses or the addition of resident species that had not been present on the 1979 to 1982 panels. Faunal composition between 1979 to 1982 and 2003 to 2006 was significantly different, with apparent shifts in species composition and dominance of species (Fig. 1; ANOSIM: $\mathrm{R}=0.310, \mathrm{p}<0.001$; Table 2). According to a 1-way SIMPER analysis, the invasive colonial ascidians Botrylloides violaceus and Didemnum vexillum, the mussel Mytilus edulis, and the sponges Haliclona loosanofi and Halichondria panicea were the most important and consistent determinants of community dissimilarity between the 1979 to 1982 and 2003 to 2006 communities (Table 3). B. violaceus and, to a lesser extent, $D$. vexillum characterized the 2003 to 2006 community and have displaced the historically prevalent blue mussel $M$. edulis (Table 4). Abundances of $M$. edulis have significantly declined since the 1979 to 1982 study ( $p<0.001$; Fig. 2A). However, between 1979 and 1982 it was a dominant and persistent spatial occupant (Fig. 2A). Unlike M. edulis, overall abundances of colonial ascidians have significantly

Table 1. Randomized complete-block 1-way ANOVA, with structural treatment as the independent variable and site as the block term. Species richness and abundance were the response variables

\begin{tabular}{|lrcrr|}
\hline & df & $\begin{array}{c}\text { Sum of } \\
\text { squares }\end{array}$ & F-ratio & Prob $>F$ \\
\hline Species richness & & & & \\
Structural treatments & 5 & 14.682986 & 38.2087 & $<0.0001$ \\
Block & 2 & 0.159723 & 1.0391 & 0.3619 \\
Error & 46 & 3.535414 & & \\
Abundance & & & & \\
Structural treatments & 5 & 857.0559 & 34.8144 & $<0.0001$ \\
Block & 2 & 10.1778 & 1.0336 & 0.3638 \\
Error & 46 & 226.4841 & & \\
\hline
\end{tabular}

Table 2. Results of a Kruskal-Wallis test used to detect temporal change in species abundances between 1979 to 1982 and 2003 to $2006(\mathrm{n}=100) .{ }^{* * *}$ significant difference at the 0.01 level in species abundances between the 1979 to 1982 and 2003 to 2006 communities; ${ }^{* *}$ significant differences at the 0.05 level; ns: not significant. Mogula sp./Obelia sp. recorded as complex

\begin{tabular}{|c|c|c|}
\hline Species & Significance & $\begin{array}{l}\text { Temporal } \\
(1979-1982 ; \\
\text { 2003-2006) } \\
\text { changes in } \\
\text { abundance }\end{array}$ \\
\hline \multicolumn{3}{|l|}{ Porifera } \\
\hline Haliclona loosanofi & $* * *$ & Decrease \\
\hline Halichondria panicea & $* * *$ & Decrease \\
\hline Leucosolenia sp. & $\mathrm{ns}$ & \\
\hline Halisarca sp. & $* * *$ & Decrease \\
\hline Yellow encrusting sponge & $* *$ & Increase \\
\hline \multicolumn{3}{|l|}{ Cnidaria } \\
\hline Ectopleura larynx & ns & \\
\hline Obelia spp. & $* *$ & Increase \\
\hline Metridium senelis & $* * *$ & Increase \\
\hline Ectopleura indivisa & $* *$ & Decrease \\
\hline Hydractinia & ns & \\
\hline \multicolumn{3}{|l|}{ Mollusca } \\
\hline Anomia simplex & $\mathrm{ns}$ & \\
\hline Mytilus edulis & $* * *$ & Decrease \\
\hline Hiatella arctica & ns & \\
\hline \multicolumn{3}{|l|}{ Gastropoda } \\
\hline Crepidula spp. & ns & \\
\hline \multicolumn{3}{|l|}{ Bryozoa } \\
\hline Membranipora membranace & & $\begin{array}{c}\text { Not present in } \\
\text { the } 1979-1982 \\
\text { community }\end{array}$ \\
\hline Bugula simplex & $* * *$ & Increase \\
\hline Bugula turrita & $* *$ & Increase \\
\hline Schizoperella unicornis & $* * *$ & Increase \\
\hline Electra pilosa & ns & \\
\hline Cryptosula pallasina & ns & \\
\hline Bowerbankia & ns & \\
\hline Hypothoa hyalina & ns & \\
\hline Encrusting bryozoans & ns & \\
\hline \multicolumn{3}{|l|}{ Tunicata } \\
\hline Botrylloides violaceus & & $\begin{array}{c}\text { Not present in } \\
\text { the } 1979-1982 \\
\text { community }\end{array}$ \\
\hline Diplosoma listerianum & & $\begin{array}{l}\text { Not present in } \\
\text { the } 1979-1982 \\
\text { community }\end{array}$ \\
\hline Botryllus schlosseri & $* * *$ & Decrease \\
\hline Didemnum vexillum & & $\begin{array}{l}\text { Not present in } \\
\text { the } 1979-1982 \\
\text { community }\end{array}$ \\
\hline Ciona intestinalis & $* * *$ & Decrease \\
\hline Molgula spp. & $* *$ & Decrease \\
\hline Aplidium constellatum & ns & \\
\hline Didemnum albidum & ns & \\
\hline Molgula sp./Obelia sp. & $* * *$ & Increase \\
\hline \multicolumn{3}{|l|}{ Crustacea } \\
\hline Balanus spp. & $* * *$ & Decrease \\
\hline Amphipod tubes & $* *$ & Increase \\
\hline
\end{tabular}




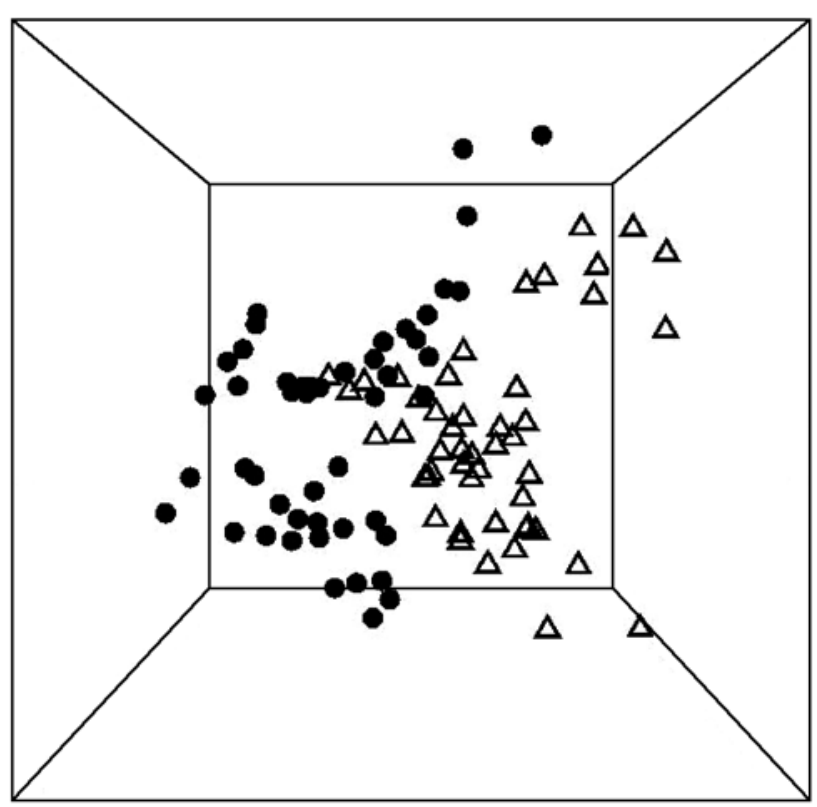

Fig. 1. Three-dimensional non-metric multidimensional scaling plot representing species assemblages between 1979 to $1982(\bullet)$ and 2003 to $2006(\Delta)$; stress 0.12. Each point represents monthly averages of abundance for both vertical and horizontal panels $(n=100)$. Significant differences in species composition were detected between 1979 to 1982 and 2003 to 2006 (ANOSIM: $\mathrm{R}=0.310, \mathrm{p}<0.001$ )

increased (Table 2, Fig. 2B). Additionally, the invasive colonial ascidians $B$. violaceus and $D$. vexillum were seasonally dominant members of the 2003 to 2006 community (Fig. 2B). Highest spatial coverage of B. violaceus occurred in summer (June through August 2004 and July through September 2005) and of D. vexillum occurred in fall and winter (October through January 2004/2005 and November through February 2005/ 2006).

Table 3. SIMPER (similarity percentage) results showing which species made the greatest contribution to the dissimilarity between 1979 to 1982 and 2003 to 2006 communities

\begin{tabular}{|c|c|c|c|c|}
\hline \multirow[t]{2}{*}{ Species } & \multicolumn{2}{|c|}{$\begin{array}{l}\text { Average abundance } \\
\text { (no. of ind. per panel) }\end{array}$} & \multirow{2}{*}{$\begin{array}{l}\text { Dissimilarity/ } \\
\text { SD }\end{array}$} & \multirow[t]{2}{*}{$\begin{array}{c}\text { Percent } \\
\text { contribution }\end{array}$} \\
\hline & $1979-1982$ & $2003-2006$ & & \\
\hline Botrylloides violaceus & 0.00 & 2.04 & 4.47 & 8.62 \\
\hline Mytilus edulis & 2.69 & 1.99 & 1.63 & 7.9 \\
\hline Ciona intestinallis & 0.99 & 0.47 & 1.43 & 3.23 \\
\hline Didemnum vexillum & 0.00 & 0.84 & 1.37 & 3.53 \\
\hline Schizoperella unicornis & 0.27 & 0.7 & 1.36 & 2.64 \\
\hline Haliclona loosanofi & 1.13 & 0.77 & 1.31 & 2.89 \\
\hline Halichondria panicea & 0.86 & 0.73 & 1.31 & 2.78 \\
\hline Metridium senelis & 0.38 & 0.59 & 1.24 & 2.4 \\
\hline
\end{tabular}

Table 4. SIMPER (similarity percentage) results showing which species made the greatest contribution to the similarity within communities. Mogula sp./Obelia sp. recorded as complex

\begin{tabular}{|c|c|c|c|c|}
\hline Species & $\begin{array}{l}\text { Avg. } \\
\text { abund. }\end{array}$ & $\begin{array}{l}\text { Avg. } \\
\text { sim. }\end{array}$ & $\begin{array}{l}\text { Similarity/ } \\
\text { SD }\end{array}$ & $\begin{array}{l}\text { Percent } \\
\text { contrib. }\end{array}$ \\
\hline \multicolumn{5}{|l|}{1982 to 1979} \\
\hline Mytilus edulis & 2.69 & 7.67 & 0.97 & 13.5 \\
\hline Anomia simplex & 1.95 & 6.57 & 3.1 & 11.57 \\
\hline Molgula sp. & 1.96 & 6.29 & 1.74 & 11.08 \\
\hline Mogula sp./Obelia sp. & 1.88 & 4.84 & 0.92 & 8.52 \\
\hline Botryllus schlosseri & 1.33 & 4.78 & 2.28 & 8.42 \\
\hline Balanus spp. & 1.94 & 4.08 & 0.82 & 7.18 \\
\hline Haliclona loosanofi & 1.13 & 3.53 & 1.27 & 6.22 \\
\hline Leucosolenia sp. & 1.02 & 3.38 & 1.68 & 5.94 \\
\hline Ciona intestinalis & 0.99 & 2.98 & 1.48 & 5.25 \\
\hline $\begin{array}{l}\text { Halichondria panicea } \\
2003 \text { to } 2006\end{array}$ & 0.86 & 2.08 & 0.95 & 3.66 \\
\hline Botrylloides violaceus & 2.04 & 7.76 & 4.37 & 13.75 \\
\hline Mogula sp./Obelia sp. & 2.96 & 6.84 & 0.89 & 12.12 \\
\hline Mytilus edulis & 1.99 & 6.1 & 1.73 & 10.8 \\
\hline Anomia simplex & 1.69 & 4.25 & 1.29 & 7.54 \\
\hline Molgula sp. & 1.56 & 3.58 & 0.98 & 6.34 \\
\hline Botryllus schlosseri & 1.05 & 3.36 & 1.65 & 5.95 \\
\hline Balanus spp. & 1.5 & 3.09 & 0.92 & 5.48 \\
\hline Haliclona loosanofi & 0.77 & 2.29 & 1.19 & 4.05 \\
\hline Didemnum vexillum & 0.84 & 2.12 & 0.94 & 3.76 \\
\hline Schizoperella unicornis & 0.7 & 1.81 & 1.04 & 3.21 \\
\hline Bugula simplex & 0.84 & 1.79 & 0.72 & 3.17 \\
\hline Leucosolenia sp. & 0.72 & 1.76 & 0.97 & 3.12 \\
\hline Halichondria panicea & 0.73 & 1.7 & 0.94 & 3.02 \\
\hline
\end{tabular}

Species richness significantly increased between the first (1979 to 1982) and the second study (2003 to 2006; Fig. 3; p < 0.01), though the total number of individuals was similar (Fig. 3A,B included monthly averages for introduced species, while Fig. 3C,D excluded monthly averages for introduced species). Further examination of species richness and abundance as a function of succession within each of the 2 communities revealed species richness was consistently higher between 2003 and 2006 than between 1979 and 1982 (Fig. 4; Fig. 4A,B include monthly averages of species and abundances, while Fig. $4 \mathrm{C}, \mathrm{D}$ exclude monthly averages of species and abundances). During the course of the experiments, species richness declined between 1979 and 1982, but no clear trend was observed between 2003 and 2006 (Fig. 4A). Abundance in terms of species numbers showed a bell-shaped distribution between 1979 and 1982: low in Year 1, increasing in Years 2 and 3, and decreasing in Year 4 (Fig. 4B,D). In contrast, abundance increased steadily from 2003 to 2006 . 

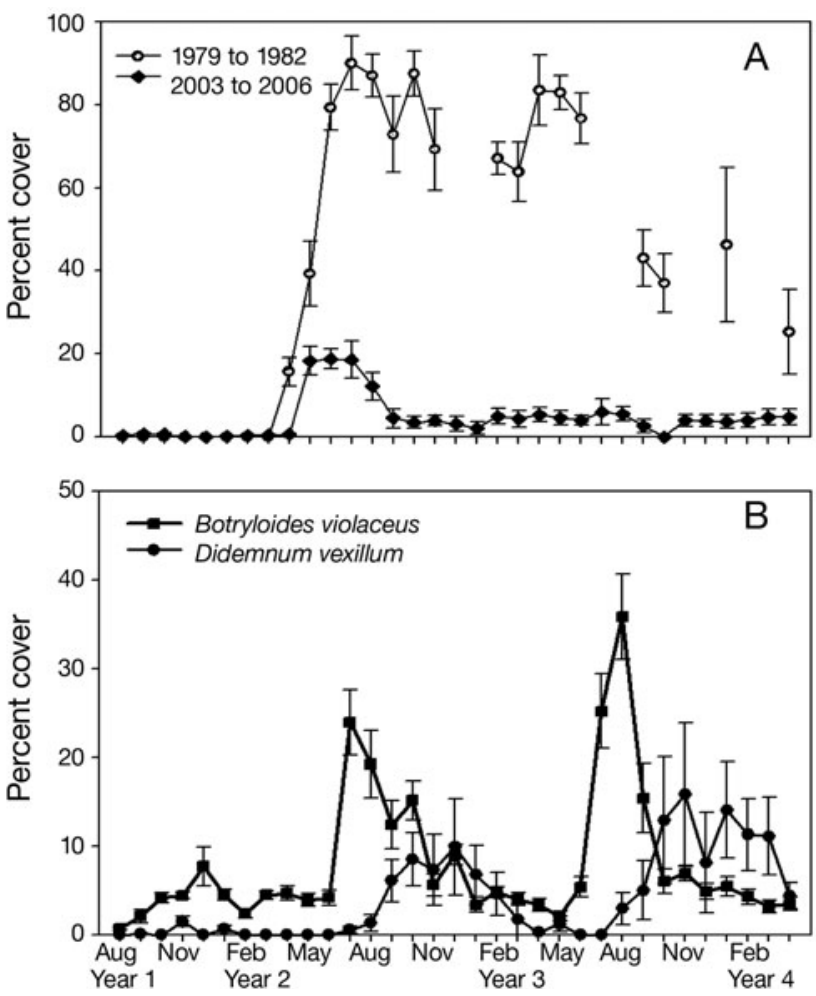

Fig. 2. (A) Percent cover $( \pm \mathrm{SE})$ of the blue mussel Mytilus edulis between 1979 to 1982 and 2003 to 2006. Presence of M. edulis has significantly declined since $1982(\mathrm{p}<0.001)$. Between 1979 and 1982, $M$. edulis dominated the panels for $\sim 21$ mo beginning in April 1980. (B) Annual percent cover $( \pm$ SE) of the recent invaders Botrylloides violaceus and Didemnum vexillum
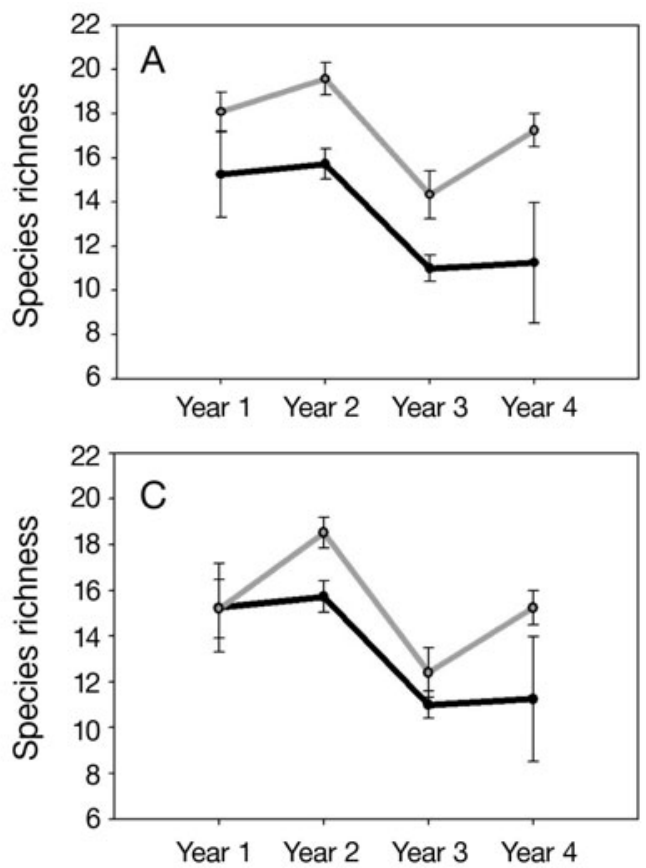
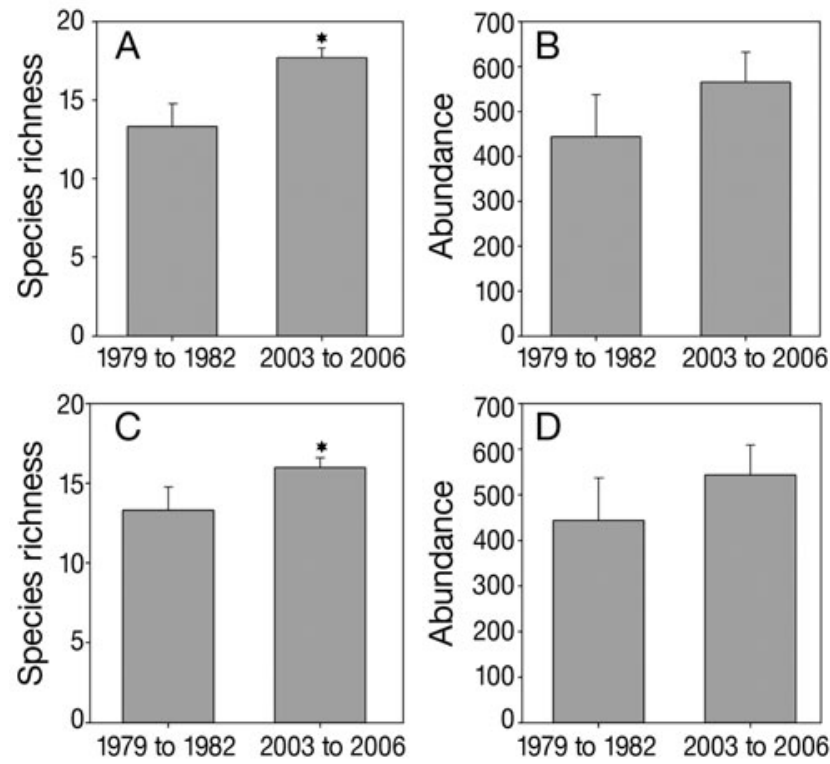

Fig. 3. Univariate measurements of species composition. Average monthly patterns of: $(A, C)$ species richness and $(B, D)$ abundance. $(A, B)$ include invasive species; $(C, D)$ do not. A 1-way ANOVA revealed a significant increase $(*)$ in species richness in the post-invasion community (A: $1 \mathrm{df}, F=13.656, \mathrm{p}<0.001$; $\mathrm{C}: 1 \mathrm{df}, F=5.801, \mathrm{p}<0.018$. (A) includes invasive species in the calculations $($ mean $=17, \mathrm{SE}=0.62)$, while $(\mathrm{C})($ mean $=15, \mathrm{SE}=$ 0.52 ) does not. Abundances of individuals were similar between the pre- and post-invasion studies when including invasive species (B: $1 \mathrm{df}, F=0.024, \mathrm{p}<0.878$; mean $=566, \mathrm{SE}=$ $66.98)$ in calculations and excluding invasive species (D: $1 \mathrm{df}$, $F=0.006, \mathrm{p}<0.938$; mean $=551, \mathrm{SE}=100$ ). Error bars were calculated using standard error
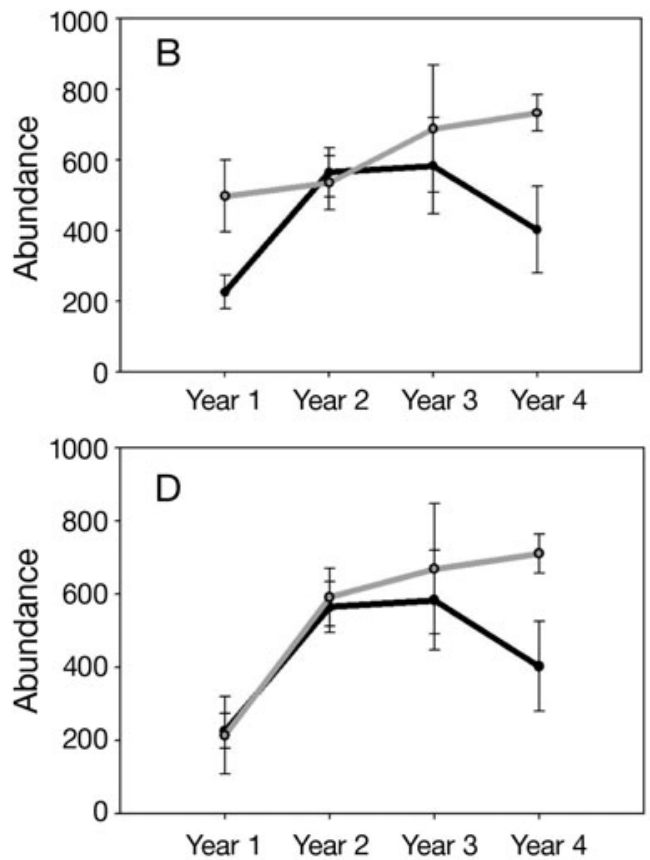

Fig. 4. Annual patterns of: (A, C) species richness and (B, D) abundance as a function of time since initial development between 1979 and 1982 (black line) and 2003 to 2006 (gray line). Annual average monthly abundances in (A) and (B) include abundances of invasive species, while (C) and (D) do not. Error bars were calculated using standard error 


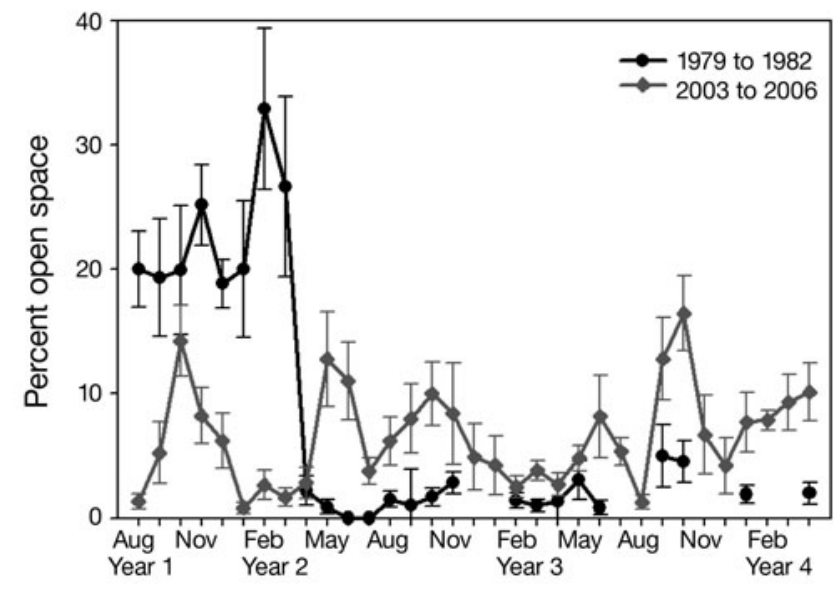

Fig. 5. Percent available bare space $( \pm \mathrm{SE})$ between 1979 to 1982 and 2003 to 2006. Total bare space increased ( $<<0.05$ ) since the initial study. Between 1979 and 1982 free space was more prevalent before the recruitment of mussels in April 1980, while primary space was stochastically available between 2003 and $2006(\mathrm{p}<0.05)$
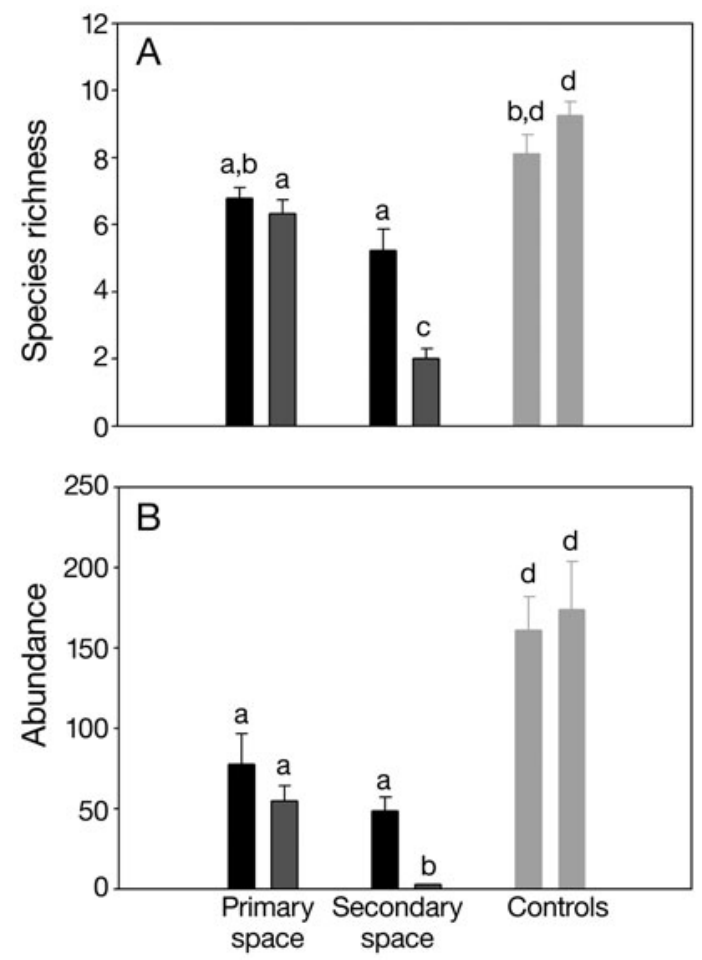

Fig. 6. The 2 wk experiments testing the response of settling larvae to secondary space provided by colonial ascidians and bivalves and to free space on panels with established adults. The Tukey-Kramer test revealed significant differences in (A) species richness and (B) abundance of recruits on bivalves versus colonial ascidians ( $\mathrm{p}<0.05)$. Additionally, secondary space provided by bivalves acted similarly to primary space on panels with established adults. No significant differences were detected on free space adjacent to adults on panels. Species richness and abundance were significantly higher on control panels than on either panel with established adults $(p<0.05)$. Different letters above bars represent significant differences
In addition to changes in community composition and species richness, there were also significant differences in the prevalence of open space between the 2 communities (Fig. 5). Between 1979 and 1982, the availability of space was linked to mussel recruitment, as a greater percent of primary space was available before the settlement of mussels in April 1980. In contrast, an increase in colonial ascidians corresponded to an increase in primary space that was stochastically available between 2003 and 2006 .

\section{Short-term experiments}

A 1-way complete-block ANOVA revealed that more individuals and species settled on (1) secondary space provided by bivalves than on secondary space provided by colonial ascidians (Fig. 6) and on (2) control panels than on panels with bivalves or colonial ascidians (Fig. 6). No significant differences were detected in the numbers of species or individuals that settled on secondary space provided by bivalves than on primary space on panels with established adults (Fig. 6; TukeyKramer set to $\mathrm{p}<0.05)$.

\section{DISCUSSION}

The present study reveals that invasive species can alter the primary mechanisms of coexistence if the structural role and life-history characteristics of the invading dominant species are significantly different than the structural role and life-history characteristics of the native dominant species. The pre-invasion community was dominated by the perennial bivalve Mytilus edulis; its hard shell maintained coexistence by providing secondary substrate for the settlement of competent larvae. In the post-invasion community, the invasive annual colonial ascidians Botrylloides violaceus and, to a lesser extent, Didemnum vexillum displaced $M$. edulis as the dominant species on the panels in spite of predators being excluded. Unlike bivalves, many colonial ascidians possess a chemical defense that deters secondary settlement (e.g. Bryan et al. 2003, Joullie et al. 2003) and inhibits predation (Lindquist et al. 1992, Pisut \& Pawlik 2002). Species coexistence in the post-invasion community was maintained instead by an increase in primary space that was facilitated by senescence and/or regression of the seasonally dominant non-native colonial ascidian species.

Historically, mussels became the dominant species on panels and ropes suspended between pier pilings that were deployed in July 1979 and February 1980 (Harris \& Irons 1982, present study). While dominance by Mytilus edulis is one of potentially many states before 
the introduction of Botrylloides violaceus and Didemnum vexillum, the decline of mussels on ropes and panels deployed in February 2003, July 2003, and April 2008 suggests a pattern of reduced mussel abundance (J. A. Dijkstra \& L. G. Harris unpubl. data, present study), though the mechanism is unclear and requires further investigation. In addition, the shift in species dominance between 1979 and 2006 was not likely the result of a region-wide decline in mussels, as mussel populations actually increased following overfishing of the green urchin Strongylocentrotus droebachiensis in the Gulf of Maine after 1995 (Harris \& Tyrrell 2001, Witman et al. 2003, Siddon \& Witman 2004).

The present study shows a positive relationship between the number of introduced species in a community and the average monthly species richness, despite a shift in dominance from a species that provided secondary substrate, e.g. mussels, to one that does not provide secondary substrate, e.g. colonial ascidians. All resident species found in the pre-invasion study were also observed in the post-invasion study. However, when excluding invasive species in our analyses, the average number of species able to occupy panels was still higher in the post-invasion community, suggesting that the life history of invasive species, rather than the invasive species themselves, is driving the increase in species richness observed between 2003 and 2006. Therefore, maintenance of species diversity has changed as a result of a shift in the structural role and life history of dominant species. Mytilus edulis is a dominant primary space occupant in intertidal and subtidal communities (Harris \& Irons 1982, Petraitis 1995). Like all bivalves, its shell provides a stable surface for the settlement of secondary space occupants (Jackson 1977, Sutherland \& Karlson 1977, Sutherland 1978, Dean \& Hurd 1980, Osman \& Whitlatch 1995b, Barnes 2001), but inhibits the amount of primary space available for settlement (present study). In contrast, Botrylloides violaceus and Didemnum vexillum are seasonally dominant species. B. violaceus grows during the spring and summer months (asexual reproduction), sexually reproducing, senescencing, and finally sloughing off panels, leaving open space for colonization. In contrast to other groups, colonial ascidians have smooth surfaces that often inhibit the attachment of species. Additionally, they have evolved chemical defenses that are highly effective deterrents to larval settlement (e.g. Buss 1976, Bryan et al. 2003, Joullie et al. 2003, Marti et al. 2003, present study). Increased availability of primary space in the post-invasion community likely counteracted the inhibitory characteristics of colonial ascidians, as higher numbers of individuals and species settle on primary versus secondary substrates (e.g. Osman \& Whitlatch 1995b, Stachowicz et al. 2002a, Clark \& Johnston 2005, Dijkstra et al. 2007b, present study).
Many studies have shown a correlation between local species richness and regional species richness. For instance, an increase in local species richness accompanied by a rise in regional species richness was found for corals in the Indo-Pacific (Karlson et al. 2004), in wetlands along the northern Coastal Range of California (Freestone \& Harrison 2006), and in various biogeographic regions from $62^{\circ} \mathrm{S}$ to $63^{\circ} \mathrm{N}$ (Witman et al. 2004). Mortality of dominant individuals not resulting from competition or predation, e.g. senescence, can lead to local temporal stochasticity of free space in subtidal communities (Connell 1978). Senescence of colonies or individuals from a single species eliminates them from an area and opens that area to recolonization, thereby, preventing competitive exclusion of species. The life-history cycle, e.g. senescence of invasive colonial ascidians, in this system created a community that is susceptible to colonization and can support regional increases in species richness.

The investigations described here also provide insight into the coexistence of species. A well-developed body of theory on species coexistence suggests that coexistence can be driven by temporal patterns of resource use (e.g. Abrams 1984, Chesson 1985, Warner \& Chesson 1985, Chesson \& Huntly 1997). Temporal changes in species presence and absence, resulting from environmental variation in a community, create patches of free space that can modify competition and enable species coexistence in local communities (Chesson 2000, Stachowicz et al. 2002b, Leibold \& Chase 2003, Leibold et al. 2004, Stachowicz \& Tilman 2005). Environmental variation in temperate zones tends to occur regularly (i.e. seasonal) and, in the absence of predation, to drive the appearance and disappearance of species in communities, as with the annual senescence of Botrylloides violaceus in the present study (e.g. Minchin 1992, Stachowicz et al. 2002b, Philippart et al. 2003, Kirby et al. 2007). A shift in dominance from a perennial species to an annual species creates annual temporal competitive relief, enabling species coexistence in this community.

Acknowledgements. The present study was partially funded by a University of New Hampshire Graduate School Teaching Fellowship, the Zoology Department and the Marine Program. Field assistance provided by H. Sherman, C. Verhille, P. Madigan, and R. Toppin was greatly appreciated. L. Kintzing, N. Rennels, N. Carlson, K. Frick and R. Toppin were encouraging and willing dive partners. We also thank W. Lambert, S. Bullard, and T. Lee for their comments on previous drafts of the manuscript. In addition, 3 anonymous reviewers significantly improved the quality of the manuscript. Finally, we thank the members of the University of New Hampshire's Coastal Marine Laboratory and the staff at Wentworth Marina and Portsmouth Commercial Fishing Pier for allowing us to riddle their docks with nylon string and many Plexiglas panels. 


\section{LITERATURE CITED}

Abrams P (1984) Variability in resource consumption rates and the coexistence of competing species. Theor Popul Biol 25:106-124

Barnes DKA (2001) The contribution of secondary space to benthic taxon richness of a coral reef: colonisation of Dendrostrea frons (Mollusca). PSZN I: Mar Ecol 22:189-200

Bryan P, McClintock J, Slattery M, Rittschof D (2003) A comparative study of the non-acidic chemically mediated antifoulant properties of three sympatric species of ascidians associated with seagrass habitats. Biofouling 19: 235-245

Bullard SG, Whitlatch RB (2004) A guide to the larval and juvenile stages of Long Island Sound ascidians and bryozoans. University of Connecticut, Groton, CT

Buss LW (1976) Better living through chemistry: the relationship between competitive networks and allelochemical interactions. In: Harrison FW (ed) Aspects of sponge biology. Academic Press, New York, p 315-328

Buss LW (1979) Habitat selection, directional growth and spatial refuges: why colonial animals have more hiding places. In: Larwood G, Rosen BR (eds) Biology and systematics of colonial organisms. Academic Press, London, p 459-497

Chesson P (1985) Coexistence of competitors in spatially and temporally varying environments: a look at the combined effects of different sorts of variable. Theor Popul Biol 28: 263-287

Chesson P (2000) General theory of competitive coexistence in spatially-varying environments. Theor Popul Biol 58: 211-237

Chesson P, Huntly N (1997) The roles of harsh and fluctuating conditions in the dynamics of ecological communities. Am Nat 150:519-553

Clark GF, Johnston EL (2005) Manipulating larval supply in the field: a controlled study of marine invasibility. Mar Ecol Prog Ser 298:9-19

- Clarke KR, Ainsworth M (1993) A method of linking multivariate community structure. Aust J Ecol 18:117-143

Clarke R, Warwick RM (2001) Change in marine communities: an approach to statistical analysis and interpretation. Plymouth Marine Laboratory, Plymouth

Connell JH (1978) Diversity in tropical rainforests and coral reefs: high diversity of trees and corals is maintained only in a nonequilibrium state. Science 199:1302-1310

> Dayton PK (1971) Competition, disturbance, and community organization: the provision and subsequent utilization of space in a rocky intertidal community. Ecol Monogr 41: 351-389

Dean TA, Hurd LE (1980) Development in an estuarine fouling community: the influence of early colonists on later arrivals. Oecologia 46:295-301

Dijkstra J, Harris LG, Westerman E (2007a) The distribution and long-term temporal patterns of four invasive colonial ascidians in the Gulf of Maine. J Exp Mar Biol Ecol 342: $61-68$

Dijkstra J, Sherman H, Harris LG (2007b) The role of colonial ascidians in altering biodiversity in marine fouling communities. J Exp Mar Biol Ecol 342:169-171

Freestone AS, Harrison S (2006) Regional enrichment is robust to variation in local productivity, abiotic gradients and heterogeneity. Ecol Lett 9:95-102

Harris LG, Irons KP (1982) Substrate angle and predation as determinants in fouling community succession. In: Cairns J (ed) Artificial substrates. Ann Arbor Science, Ann Arbor, MI, p. 131-174
Harris LG, Tyrrell MC (2001) Changing community states in the Gulf of Maine: synergisms between invaders, overfishing and climate change. Biol Invasions 3:9-21

Jackson JBC (1977) Competition on marine hard substrata: the adaptive significance of solitary and colonial strategies. Am Nat 111:743-767

Joullie MM, Leonard MS, Portonovo P, Liang B, Ding X, Clair JJL (2003) Chemical defense in ascidians of the Didemnidae family. Bioconjug Chem 14:30-37

Karlson RH, Cornell HV, Hughes TP (2004) Coral communities are regionally enriched along an oceanic biodiversity gradient. Nature 429:867-870

> Kirby RR, Beaugrand G, Lindley JA, Richardson AJ, Edwards M, Read PC (2007) Climate effects and benthic pelagic coupling in the North Sea. Mar Ecol Prog Ser 330:31-38

Leibold M, Chase J (2003) Ecological niches: linking classical and contemporary approches. University of Chicago Press, Chicago, IL

Leibold M, Holyoak M, Mouquet N, Amarasekare P, Chase J, Hoopes M (2004) The metacommunity concept: a framework for multi-scale community ecology. Ecol Lett 7:601-613

Levine JM (2000) Species diversity and biological invasions: relating local processes to community pattern. Science 288:852-854

> Levine JM, D'Antonio CM (1999) Elton revisited: a review of evidence linking diversity and invasibility. Oikos 87:15-26

$>$ Lindquist N, Hay ME, Fenical W (1992) Defense of ascidians and their conspicuous larvae: adult vs larval chemical defenses. Ecol Monogr 62:547-568

Lonsdale WM (1999) Global patterns of plant invasions and the concept of invasibility. Ecology 80:1522-1536

> Lundholm JT, Larson DW (2004) Dominance as an overlooked measure of invader success. Biol Invasions 6:505-510

> Marti R, Fontana A, Uriz MJ, Cimino G (2003) Quantitative assessment of natural toxicity in sponges: toxicity bioassay versus compound quantification. J Chem Ecol 29: $1307-1318$

Minchin D (1992) Multiple species, mass spawning events in an Irish sea lough: the effects of temperatures on spawning and recruitment of invertebrates. Invertebr Reprod Dev 22:229-238

Osman RW, Whitlatch RB (1995) Ecological factors controlling the successful invasion of three species of ascidians into marine subtidal habitats in New England. In: Balcom NC (ed) Proceedings of the Northeast Conference on NonIndigenous Aquatic Nuisance Species: a regional conference. Cromwell, CT, Pub. No. CT-SG-95-04. Connecticut Sea Grant College Program, Groton, CT, p 49-60

> Osman RW, Whitlatch RB (1995b) The influence of resident adults on recruitment? A comparison to settlement. J Exp Mar Biol Ecol 190:169-198

Petraitis P (1995) The role of growth in maintaining spatial dominance by mussels (Mytilus edulis). Ecology 76: $1337-1346$

Philippart CJM, Van Aken HM, Beukema JJ, Bos OG, Cade'e GC, Dekker R (2003) Climate-related changes in recruitment of the bivalve Macoma balthica. Limnol Oceanogr 48:2171-2185

Pisut DP, Pawlik JR (2002) Anti-predatory chemical defenses of ascidians: secondary metabolites or inorganic acids? J Exp Mar Biol Ecol 270:203-214

Pollock LW (1998) A practical guide to the marine animals of northeastern North America. Rutgers University Press, New Brunswick, NJ

Reiss H, Knauper S, Kroncke I (2003) Invertebrate associations with gastropod shells inhabited by Pagurus bernhardus (Paguridae) — secondary hard substrate increasing 
biodiversity in North Sea soft-bottom communities. Sarsia 88:404-414

Sala E, Knowlton N (2006) Global marine biodiversity trends. Annu Rev Environ Resour 31:93-122

Sebens KP (1982) Competition for space: growth rate, reproductive output, and escape in size. Am Nat 120:189-197

Siddon CE, Witman JD (2004) Behavioral indirect interactions: multiple predator effects and prey switching in the rocky subtidal. Ecology 85:2938-2945

Simberloff D, Dayan T (1991) The guild concept and the structure of ecological communities. Annu Rev Ecol Syst 22: $115-143$

Sousa WP (1984) The role of disturbance in natural communities. Annu Rev Ecol Syst 15:353-391

Stachowicz JJ, Byrnes JE (2006) Species diversity, invasion success, and ecosystem functioning: disentangling the influence of resource competition, facilitation, and extrinsic factors. Mar Ecol Prog Ser 311:251-262

Stachowicz JJ, Tilman D (2005) Species invasions and the relationships between species diversity, community saturation, and ecosytem functioning. In: Sax DF, Stachowicz JJ, Gaines S (eds) Species invasions: insights into ecology, evolution, and biogeography. Sinauer Associates, Sunderland, MA, p 41-64

Stachowicz JJ, Whitlatch RB, Osman RW (1999) Species diversity and invasion resistance in a marine ecosystem. Science 286:1577-1579

Stachowicz JJ, Fried H, Osman RW, Whitlatch RB (2002a) Biodiversity, invasion resistance, and marine ecosystem function: reconciling pattern and process. Ecology 83:2575-2590

Editorial responsibility: Richard Osman,

Edgewater, Maryland, USA
Stachowicz JJ, Terwin JR, Whitlatch RB, Osman RW (2002b) Linking climate change and biological invasions: ocean warming facilitates nonindigenous species invasions. Proc Natl Acad Sci USA 99:15497-15500

Stachowicz JJ, Bruno JF, Duffy JE (2007) Understanding the effects of marine biodiversity on communities and ecosystems. Annu Rev Ecol Evol Syst 38:739-766

Sutherland JP (1978) Functional roles of Schizoporella and Styela in the fouling community at Beaufort, North Carolina. Ecology 59:257-264

Sutherland JP, Karlson RH (1977) Development and stability of the fouling community at Beaufort, North Carolina. Ecol Monogr 47:425-446

- Warner RR, Chesson PL (1985) Coexistance mediated by recruitment fluctuations: a field guide to the storage effect. Am Nat 125:769-787

Witman JD, Genovese SJ, Bruno JF, McLaughlin JW, Pavlin BI (2003) Massive prey recruitment and the control of rocky subtidal communities on large spatial scales. Ecol Monogr 73:441-462

Witman JD, Etter RJ, Smith F (2004) The relationship between regional and local species diversity in marine benthic communities: a global perspective. Proc Nat Acad Sci USA 101: 15664-15669

Yund PO, Marcum Y, Stewart-Savage J (1997) Life-history variation in a colonial ascidian: broad-sense heritabilities and tradeoffs in allocation to asexual growth and male and female reproduction. Biol Bull 192:290-299

Zar JH (1999) Biological statistics. Prentice Hall, Englewood Cliffs, NJ

Submitted: September 10, 2008; Accepted: May 18, 2009

Proofs received from author(s): July 17, 2009 